\title{
Efektivitas E-Modul Berbasis Anyflip untuk Meningkatkan Kemampuan Penguasaan Materi Peserta Didik pada Materi Nilai dan Norma Sosial Kelas X di SMA N 3 Payakumbuh
}

\author{
Arena Santika ${ }^{1}$, Ike Sylvia ${ }^{2}$ \\ ${ }^{1,2}$ Universitas Negeri Padang \\ Email: arenasantika22@gmail.com, ikesylvia@fis.unp.ac.id
}

\begin{abstract}
Abstrak
Penelitian ini dilatarbelakangi karena rendahnya kemampuan kognitifpeserta didik dalam memahami materi pembelajaran. Tujuan dari penelitian ini adalah untuk menghasilkan modul elektronik (e-modul) yang efektif meningkatkan kemampuan penguasaan materi peserta didik pada pembelajaran sosiologi SMA khusunya keals X. E-modul yang dimaksud dalam penelitian ini adalah e-modul berbasis anyflip yang efektif digunakan oleh peserta didik. Untuk menguji efektifitas tersebut peneliti menggunakan metode penelitian eksperimen dengan desain one group pretest and posttest design. E-modul berbasis anyflip yang dihasilkan ini dapat dilihat keefektifannya melalui hasil belajar peserta didik dalam meningkatkan penguasaan materi melalui soal pretest-posttest. Uji coba dilakukan pada peserta didik kelas X IPS 4 di SMA N 3 Payakumbuh, dengan jumlah sampel sebanyak 34 orang. Dapat dilihat dari perbedaan rata-rata hasil nilai pretest sebesar 72,82 dan rata-rata hasil posttest sebesar 87,05. Analisa data dilakukan dengan menggunakan uji normalitas data, uji homogenitas data dan uji hipotesis. Hasil uji normalitas dan homogenitas memperlihatkan data pretest dan posttest normal dan homogen. Uji hipotesis dilakukan dengan menggunakan formula uji $\mathrm{t}(\mathrm{t}$-test) yang memperlihatkan nilai $t$ hitung yang diperoleh adalah 1,80 dan nilai $t$ tabel dengan df 66 adalah 1,671, sehingga nilai $t$ hitung $>t$ tabel. Hasil ini memperlihatkan bahwa terdapat pengaruh penggunaan e-modul berbasis anyflip pada pembelajaran sosiologi SMA kelas X IPS 4 materi nilai dan norma sosial terhadap hasil belajar mereka. Artinya penggunaan e-modul berbasis anyflip pada pembelajaran sosiologi SMA kelas X materi nilai dan norma sosial efektif dan mampu meningkatkan hasil belajar peserta didik di kelas X IPS 4 SMAN 3 Payakumbuh, khususnya materi nilai dan norma sosial.
\end{abstract}

Kata kunci: Anyflip, Efektivitas, E-Modul, Pembelajaran Sosiologi

\begin{abstract}
This research is motivated by the low cognitive abilities of students in understanding learning material. The purpose of this research is to produce an electronic module (e-module) which effectively improves the students' mastery of material in high school sociology learning, especially X class. The e-module referred to in this study is an anyflip-based emodule which is effectively used by students. To test the effectiveness, the researcher used an experimental research method with a one group pretest and posttest design. The effectiveness of the anyflip-based e-module produced can be seen through the learning outcomes of students in increasing mastery of the material through pretest-posttest questions. The trial was carried out on students of class X IPS 4 at SMA N 3 Payakumbuh, with a sample size of 34 people. It can be seen from the difference in the average pretest score of 72.82 and the average posttest result of 87.05. Data analysis was carried out using data normality test, data homogeneity test and hypothesis testing. The results of the normality and homogeneity tests showed that the pretest and posttest data were normal and homogeneous. Hypothesis testing is carried out using the t-test formula (t-test) which shows $n$ The $t$ value obtained is 1.80 and the value of t table with df 66 is 1.671, so that the value of t count $>$ t table. These results show that there is an effect of the use of anyflip-based e-module on sociology learning for class X IPS 4 on social values and norms on their learning outcomes. This means that the use of anyflip-based emodule in class $X$ high school sociology learning material values and social norms is effective and can improve student learning outcomes in class X IPS 4 SMAN 3 Payakumbuh, especially material values and social norms.
\end{abstract}

Keywords: Anyflip, Effectiveness, E-Module, Sociology Learning

Received: May 5, 2021 Revised: June 1, 2021 Accepted: June 2, 2021 


\section{Pendahuluan}

Pemilihan teknologi yang tepat dalam pendidikan akan menghasilkan berbagai alternatif bentuk fasilitas yang dapat digunakan dalam proses belajar. Dengan adanya inovasi penerapan teknologi dalam pembelajaran akan membuat terjadinya perubahan besar dalam interaksi belajar mengajar antara sumber-sumber belajar dengan pelaku belajar. Berdasarkan UU No. 20 Tahun 2003 tentang pendidikan nasional (Grasindo, 2017), dunia pendidikan dituntut untuk terus meningkatkan kualitasnya baik dalam hal sarana dan prasarana termasuk juga kualitas praktik pembelajaran. Hal ini dirasakan selama proses belajar yang terjadi pada masa pandemi covid-19 mulai dari Maret 2020. Kegiatan belajar di sekolah yang semula berlangsung tatap muka mulai beralih menjadi pembelajaran berbasis online pada Maret 2020 hingga Desember 2021, yang kemudian menggunakan sistem blended learning pada Januari 2021. Kenyataan ini mengharuskan para pendidik dan peserta didik untuk melakukan literasi dari berbagai sumber belajar agar dapat mengeksplorasi berbagai materi yang dapat menunjang proses pembelajaran tersebut.

Sumber belajar yang sering digunakan pada mata pelajaran sosiologi di kelas X SMA N 3 Payakumbuh adalah LKPD, buku sumber siswa dan modul yang dibuat oleh guru mata pelajaran. Namun pada proses pembelajaran sosiologi yang dilaksanakan semester Juli-Desember 2020 tidak semua peserta didik memiliki LKPD dan buku paket. Hal ini disebabkan karena peserta didik sama sekali belum berinteraksi dengan pembelajaran di SMA, belum pernah ke sekolah dan terbatas karena kondisi pandemi covid1-19. Modul yang diberikan kepada peserta didik selama pembelajaran daring ini dibuat oleh masing-masing guru mata pelajaran di sekolah, namun modul yang dibuat ini sebenarnya adalah versi cetak. Modul yang dibuat oleh guru berisikan teks mengenai materi yang dipelajari yang diambil dari berbagai sumber, baik itu dari buku paket maupun dari internet. Kemudian versi cetak inilah yang dikirimkan oleh guru ke grup whatsapp ataupun di upload ke google classroom. Oleh karena itu modul ini memiliki kelemahan yaitu kurang praktis dan menggunakan kertas yang persediaannya terbatas.

Berdasarkan hasil observasi di kelas X IPS 4 SMA N 3 Payakumbuh pada semester ganjil pada tahun ajaran 2020/2021 ditemukan berbagai masalah yang dihadapi guru pada proses pembelajaran pada mata pelajaran sosiologi kelas X IPS 4. Masalah utama terdapat pada pencapaian hasil belajar dalam ranah kognitif (penguasaan materi) peserta didik masih rendah dikarenakan pembelajaran dilaksanakan secara online. Selain itu guru belum bisa mengoptimalkan penggunaan sumber belajar seperti video pembelajaran, e-modul dll. Berdasarkan hasil wawancara dengan guru mata pelajaran sosiologi mengungkapkan bahwa guru memerlukan sebuah modul pembelajaran yang terintegrasi materi pembelajaran. Menurut (Purwanto \& Lasmono, 2007) tujuan disusunnya modul ialah agar peserta didik dapat menguasai kompetensi yang diajarkan dalam kegiatan pembelajaran dengan sebaik-baiknya. Untuk itu perlu adanya sumber belajar elektronik yang dapat digunakan guru dan peserta didik sebagai sumber pembelajaran. Menurut (Majid, 2013), sumber belajar merupakan berbagai bentuk informasi yang disajikan dalam bentuk media dan dapat digunakan siswa sebagai alat bantu belajar untuk melakukan proses perubahan tingkah laku. Salah satu sumber belajar elektronik tersebut yaitu elektronik modul. E-modul yang akan dihasilkan ini terdiri dari beberapa komponen yaitu materi, gambar, dan hal menarik lainnya. E-modul ini juga bsa digunakan menjadi sumber belajar mandiri peserta didik. E-modul yang akan digunakan yaitu e-modul berbasis anyflip yang digunakan melalui smartphone atau laptop. Penggunaan e-modul ini tidak dibatasi tempat dan waktu, tergantung sarana dan prasarana yang dimiliki peserta didik dalam mengakses e-modul.

Pengembangan sumber belajar untuk peserta didik perlu dilakukan guru sebagai bentuk usaha guru dalam inovasi dalam pembelajaran dan meningkatkan kompetensi peserta didik. Sumber belajar yang menarik dapat digunakan sebagai sarana pembelajaran yang dapat membantu peserta didik untuk memudahkan dalam memahami materi dan mengingat materi tersebut. Biasanya modul yang dibuat oleh guru hanya seperti bahan ajar yang berisikan tulisan- 
Arena Santika, Ike Sylvia

Efektivitas E-modul Berbasis Anyflip untuk Meningkatkan Kemampuan Penguasaan Materi Peserta Didik pada Materi Nilai dan Norma Sosial Kelas X di SMA N 3 Payakumbuh

tulisan serta soal latihan yang akan dikerjakan peserta didik. Seharusnya sumber pembelajaran harus dikemas semenarik mungkin dan juga mengikuti perkembangan teknologi pembelajaran di era digital ini, agar peserta didik lebih termotivasi dan paham dengan materi yang dipelajari. Emodul sangat berperan penting dalam pembelajaran di sekolah karena elektronik modul ini sebagai alat membantu guru dalam kegiatan pembelajaran. Penelitian ini bertujuan untuk melihat keefektifan e-modul berbasis anyflip sebagai sarana sumber belajar untuk meningkatan kemampuan penguasaan materi peserta didik.

\section{Metode Penelitian}

Metode penelitian yang digunakan adalah metode eksperimen dengan desain one group pretest and posttest design. Sebelumnya peneliti telah mengembangkan e-modul berbasis anyflip, dan pada penelitian ini khusus untuk mengujicobakan e-modul yang telah dirancang tersebut untuk melihat efektifitas penggunaan e-modul dalam pembelajaran sosiologi SMA kelas X. Menurut Permana (Permana \& Johar, 1999) metode eksperimen diartikan sebagai cara belajar mengajar yang melibatkan siswa dengan mengalami dan membuktikan sendiri proses dan hasil percobaan. Penelitian dilakukan di SMA N 3 Payakumbuh dengan sampel penelitian adalah peserta didik kelas X IPS 4 yang berjumlah 34 peserta didik. Pemilihan kelas ini juga didasarkan pada nilai terendah yang diperoleh dari UH 1 peserta didik kelas X IPS tersebut pada semester Juli-Desember 2020.

Penelitian ini menggunakan satu kelas uji coba. Penelitiaan diawali dengan memberikan tes awal (pre test) kepada kelas eksperimen untuk mengetahui kemampuan awal serta didik pada materi nilai dan norma sosial. Hasil pre test dari kelas tersebut diolah untuk mendapatkan rata-rata nilai yang dicapai peserta didik.

Tahap berikutnya pada kelas eksperimen, peneliti menerapkan pembelajaran sosiologi menggunakan bantuan e-modul yang telah dirancang. Setelah pembelajaran pada kelas eksperimen selesai, siswa kelas eksperimen diberikan evaluasi akhir (post test), kemudian hasil evaluasi akhir dari kelas eksperimen tersebut dibandingkan, agar dapat diketahui perbedaan hasil pembelajaran antara sebelum pemberian e-modul dan sesudahnya, dari skor pretest dan posttest peserta didik.

Dalam melakukan penelitian, teknik pengumpulan data dilakukan dengan pemberian soal tes pada peserta didik. Soal tes diberikan di awal pembelajaran sebelum e-modul diujicobakan atau disebut dengan pretest. Kemudian peneliti melakukan posttest setelah ujicoba e-modul dilakukan. Soal yang diberikan berjenis pilihan ganda yang terdiri dari 35 soal yang akan menguji penguasaan peserta didik terhadap materi pengertian nilai dan norma sosial, ciri-ciri nilai dan norma sosial, fungsi dari nilai sosial dan norma sosial, jenis-jenis nilai dan norma sosial, proses terbentuknya norma sosial. Untuk melakukan analisis data pada efektivitas elektronik modul berbasis anyflip, terlebih dahulu dilakukan uji normalitas dan homogenitas data dari skor pretest dan posttest peserta didik. Selanjutnya uji hipotesis dianalisis berdasarkan skor pretest dan posttest peserta didik dengan menggunakan formula rumus uji $\mathrm{t}(\mathrm{t}$-test) untuk melihat efektivitas e-modul berbasis anyflip yang digunakan peserta didik dalam proses pembelajaran sosiologi SMA kelas X IPS 4 di SMA N 3 Payakumbuh.

\section{Hasil dan Pembahasan}

Kemampuan kognitif adalah proses yang terjadi secara internal di dalam pusat susunan syaraf pada waktu manusia sedang berpikir. Menurut Abdurrahman kemampuan kognitif berkembang secara bertahap, sejalan dengan perkembangan fisik dan syaraf-syaraf yang berada di pusat susunan syaraf. Perkembangan kognitif berfokus pada keterampilan berfikir, belajar, pemecahan masalah, rasional, dan mengingat. Perkembangan kognitif sendiri adalah proses yang

Jurnal Sikola: Jurnal Kajian Pendidikan dan Pembelajaran Vol. 2, No. 4, Th. 2021 
terjadi secara internal di dalam pusat susunan syaraf pada waktu manusia sedang berfikir (Ibda, 2015).

Sedangkan hasil belajar adalah kompetensi atau kemampuan tertentu baik kognitif, afektif maupun psikomotorik yang dicapai atau dikuasai peserta didik setelah mengikuti proses belajar mengajar (Kunandar, 2013). Menurut Sudjana (Sudjana, 2010), hasil belajar adalah kemampuan yang dimiliki siswa setelah menerima pengalaman belajar. Selanjutnya Warsito (Depdiknas, 2016) mengemukakan bahwa hasil dari kegiatan belajar ditandai dengan adanya perubahan perilaku ke arah positif yang relatif permanen pada diri orang yang belajar. Sehubungan dengan pendapat itu, maka Wahidmurni (Wahidmurni, Mustikawan, \& Ridho, 2010) menjelaskan bahwa sesorang dapat dikatakan telah berhasil dalam belajar jika ia mampu menunjukkan adanya perubahan dalam dirinya. Perubahan-perubahan tersebut di antaranya dari segi kemampuan berpikirnya, keterampilannya, atau sikapnya terhadap suatu objek.

Penelitian ini sebelumnya telah menghasilkan produk berupa e-modul berbasis anyflip pada pembelajaran sosiologi materi nilai dan norma sosial yang akan digunakan peserta didik kelas X IPS 4. Menurut Fajaryati (Fajaryati, Nurkhamid, Pranoto, Muslikhin, \& Dwi W, 2016) bahwa emodul didefenisikan sebagai modul digital yang dibuat menjadi interaktif. E-modul juga merupakan salah satu bahan ajar yang berfungsi membantu peserta didik dalam mempelajari dan memahami materi pembelajaran secara mandiri dengan media elektronik (Syahrial, Asrial, Kurniawan, \& Piyana, 2019). E-modul yang dihasilkan dibuat menggunakan program microsoft word dan selanjutnya dikonversi menjadi format e-modul menggunakan aplikasi anyflip. Berikut adalah contoh desain e-modul yang telah dikembangkan:

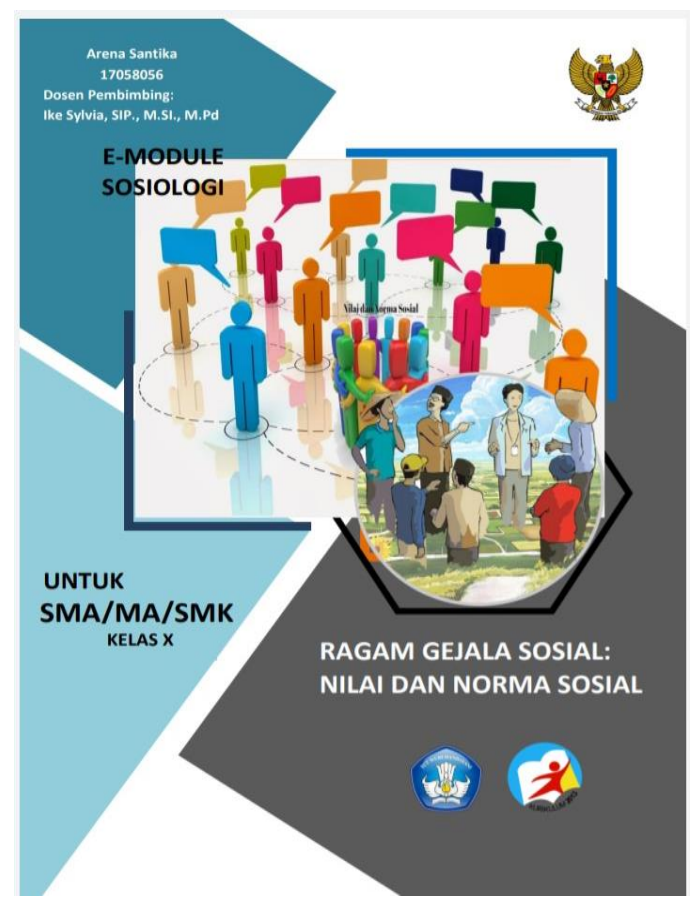

Gambar 1. Cover E-Modul berbasis Anyflip
Sumber: Data Primer Hasil Pengembangan (2021)

Pada gambar 1, terdapat rancangan halaman depan di isi dengan identitas yang membuat emodul, judul mata pelajaran, materi dan gambar yang menarik sesuai dengan materi pembelajaran. 


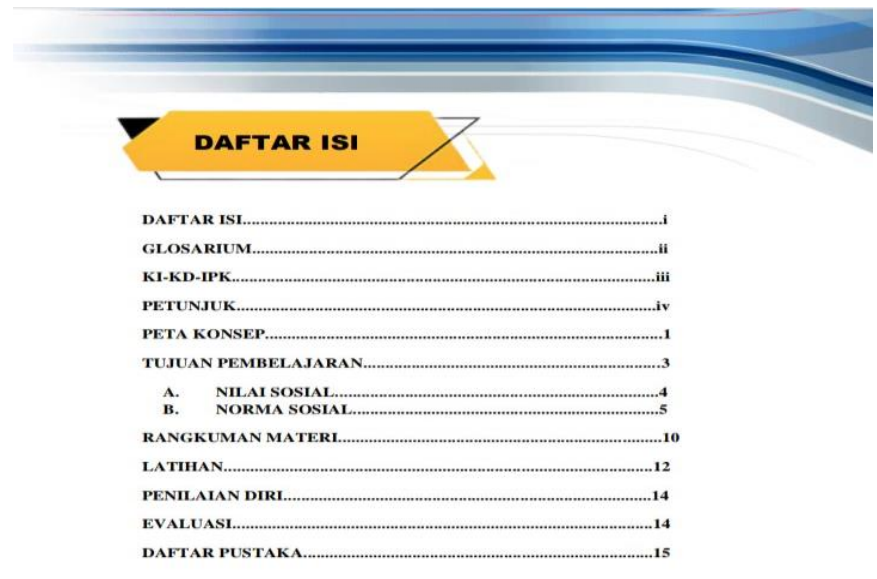

NILAI DAN NORMA SOSIAL KELAS $X$

Gambar 2. Daftar Isi E-Modul berbasis Anyflip

Sumber: Data Primer Hasil Pengembangan (2021)

Pada gambar 2, terdapat tampilan daftar isi materi nilai dan norma sosial.

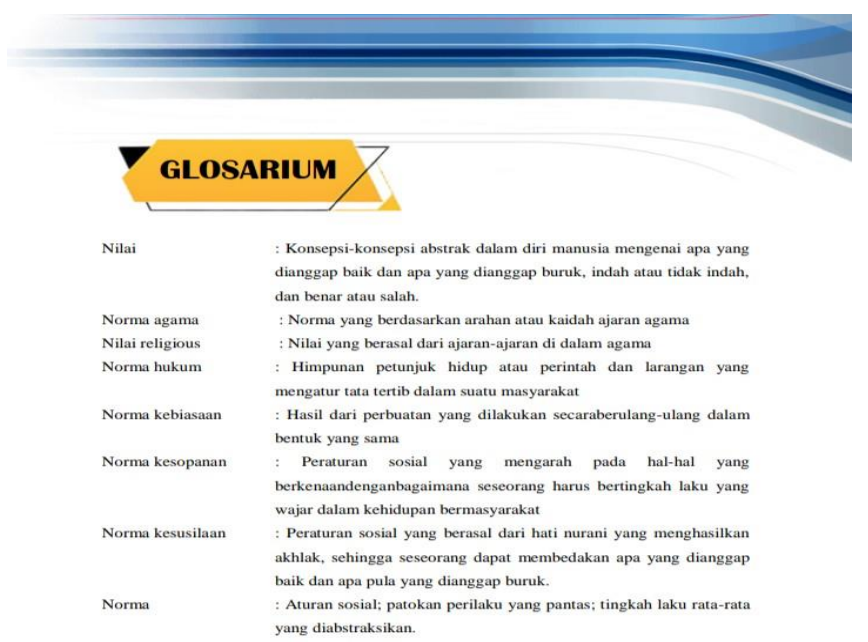

NILAI DAN NORMA SOSIAL KELAS $x \quad$ ii

\section{Gambar 3. Glosarium}

Sumber: Data Primer Hasil Pengembangan (2021) 
Pada gambar 3 terdapat rangkuman glosarium yaitu kalimat-kalimat istilah yang ada pada e-modul berbasis anyflip.

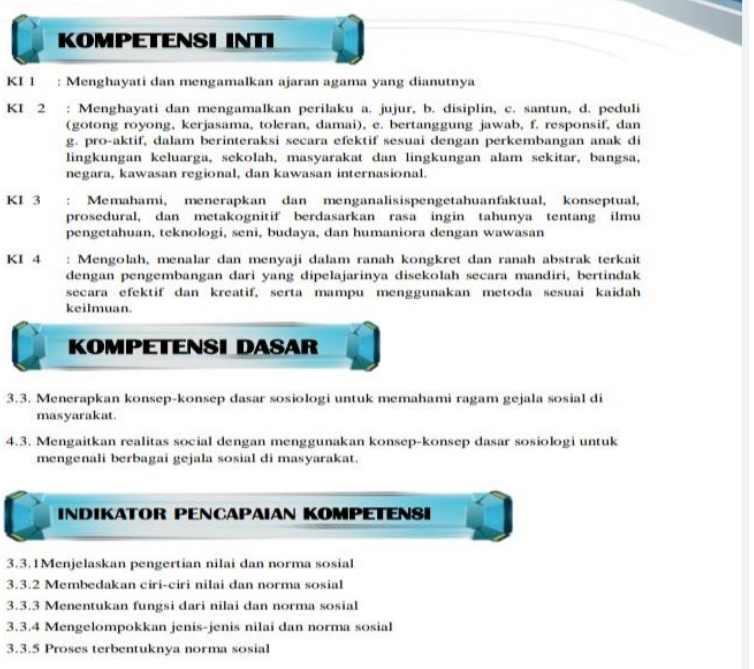

\section{Gambar 4. Kompetensi Inti, Kompetensi Dasar dan IPK}

Sumber: Data Primer Hasil Pengembangan (2021)

Pada gambar 4 dijelaskan bahwa pada e-modul berisikan KI, KD, dan IPK agar peserta didik paham bahwa dalam belajar harus sesuai dengan indikator pembelajaran.

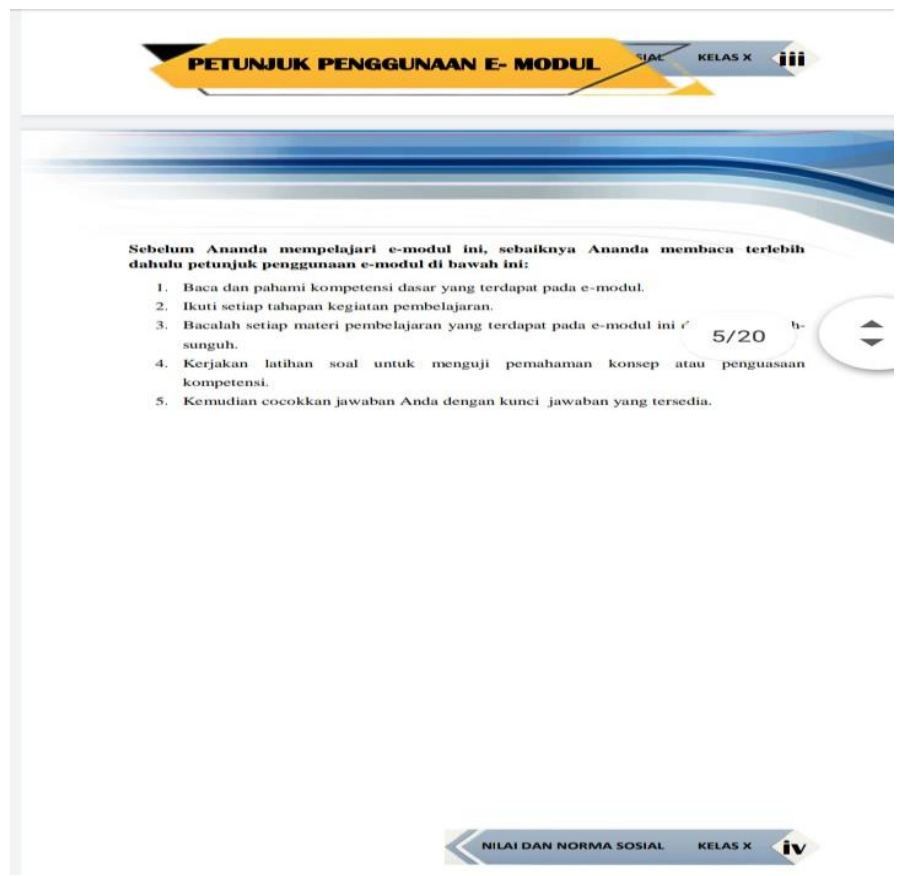

Gambar 5. Petunjuk Penggunaan E-Modul

Sumber: Data Primer Hasil Pengembangan (2021) 
Pada gambar 5 terdapat petunjuk dalam penggunaan e-modul berbasis anyflip.

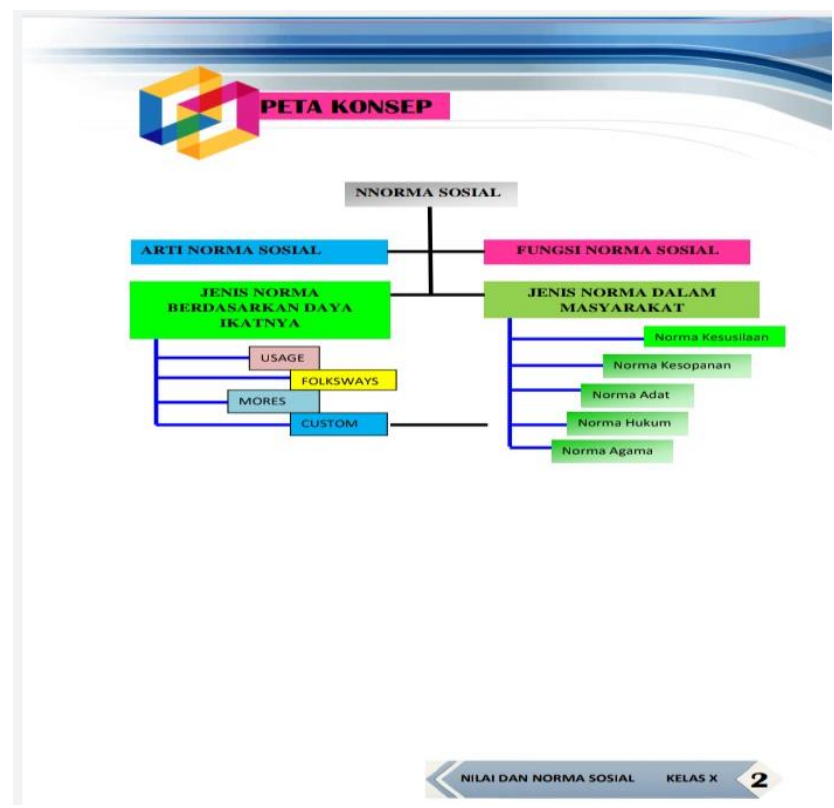

Gambar 6. Peta Konsep Nilai Sosial

Sumber: Data Primer Hasil Pengembangan (2021)

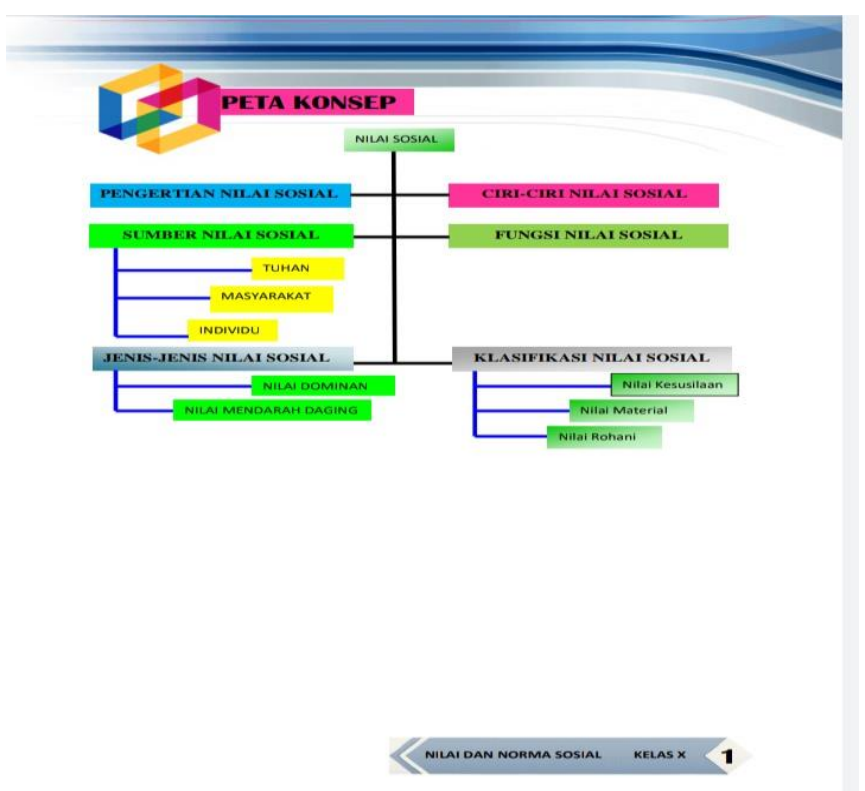

Gambar 7. Peta Konsep Norma Sosial

Sumber: Data Primer Hasil Pengembangan (2021)

Pada gambar 6 dan 7 berisikan peta konsep tentang materi nilai dan norma sosial. 
Setelah mengikuti kegiatan pembelajaran dengan pendekatan saintific menggunak model pembelajaran discovery learning serta melakukan diskusi lewat whattsap group, siswa di harapkan bisa untuk terlibat aktif dalam proses pembelajaran, bersikap ingin tah dan teliti , serta siswa mampu untuk menjelaskan dan membedakan pengertian nilai dan normasosial, ciri-ciri nilai dan norma , fungsi nilai dan norma serta bentuk-bentuk dari nila dan norma sosial.

Gambar 8. Tujuan Pembelajaran

Sumber: Data Primer Hasil Pengembangan (2021)

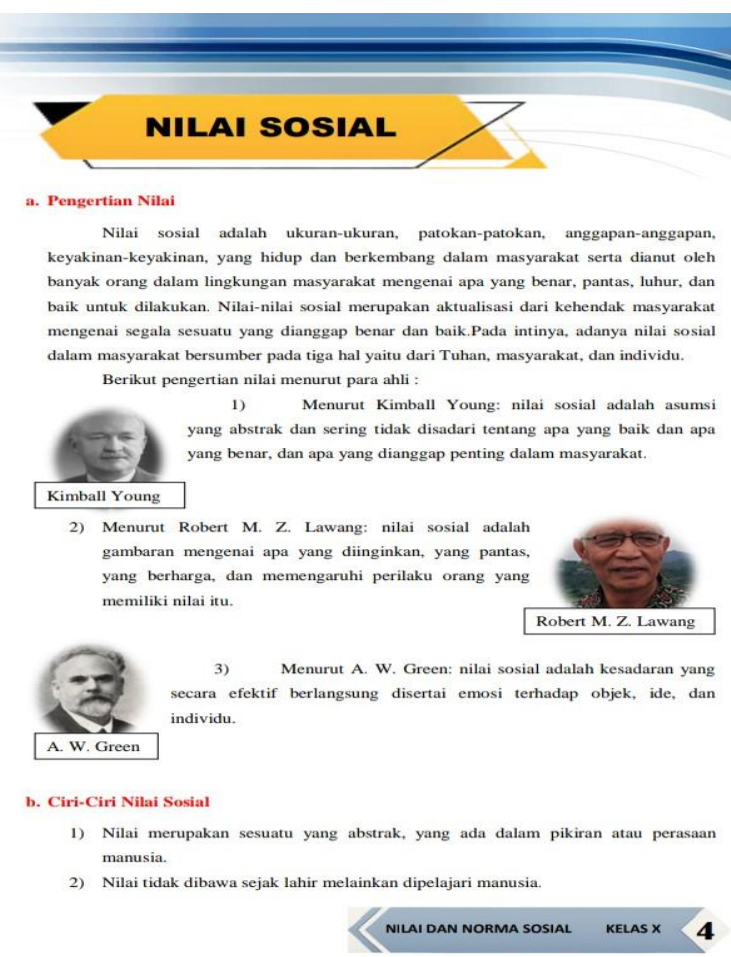

Gambar 9. Materi Nilai Sosial

Sumber: Data Primer Hasil Pengembangan (2021) 


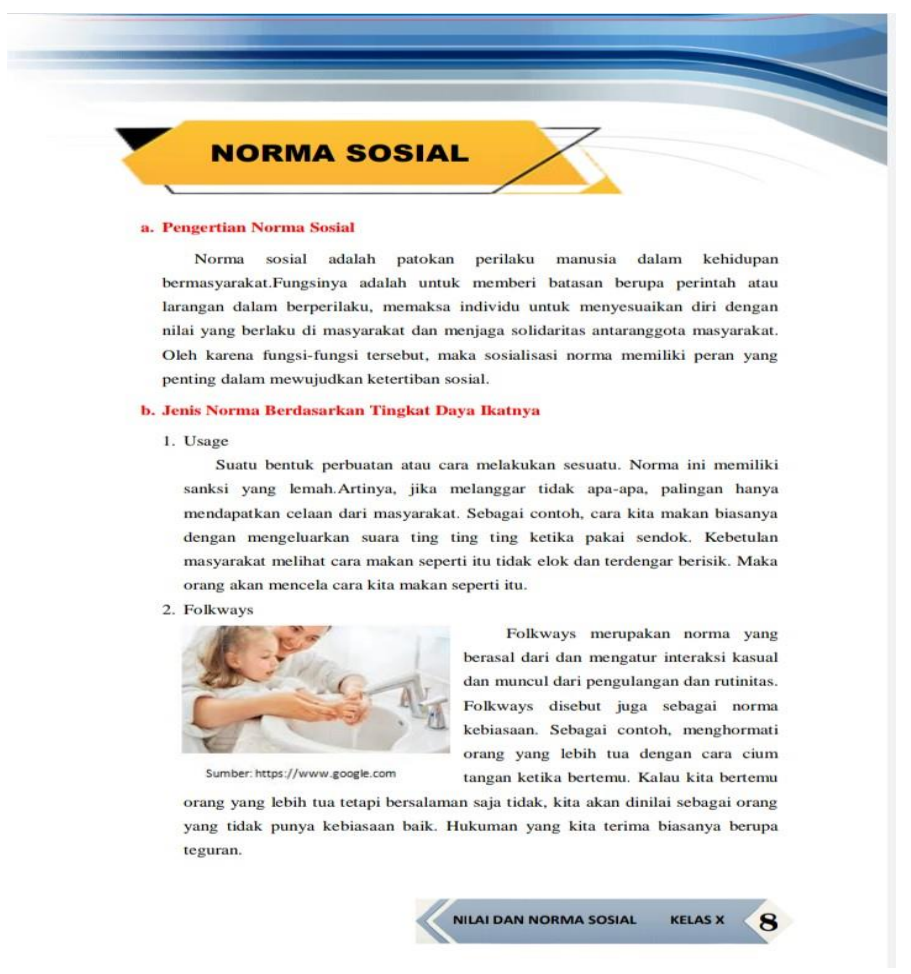

\section{Gambar 10. Materi Norma Sosial}

Sumber: Data Primer Hasil Pengembangan (2021)

Pada gambar 9 dan 10 dijelaskan tentang materi nilai dan norma sosial yang akan dipahami peserta didik dengan guru.

Pada e-modul juga disajikan rangkuman dari materi, dan terdapat juga latihan soal atau evaluasi untuk menguji pemahaman materi peserta didik. E-modul dapat digunakan sebagai alat untuk melengkapi bahan ajar yang digunakan oleh guru dalam proses pembelajaran dan e-modul dapat membantu guru dalam menjelaskan materi pelajaran. E-modul disini memiliki peran penting dalam proses pembelajaran. Proses pembelajaran bisa berlangsung dengan efektif apabila menggunakan elektronik modul karena bisa membantu peserta didik yang mengalami kendala dalam belajar. E-modul bisa membantu peserta didik untuk belajar secara mandiri baik di sekolah maupun di rumah dan dapat mengukur tingkat pemahamannya sendiri karena e-modul ini dilengkapi dengan peta konsep, materi dan evaluasi. Berikut ini adalah kisi-kisi soal yang digunakan dalam pretest dan posttest.

Tabel 1. Kisi-Kisi Soal Pretest-Posttest

\begin{tabular}{llcl}
\hline No & \multicolumn{1}{c}{ Indikator soal } & Tipe soal & No soal objektif \\
\hline 1. & $\begin{array}{l}\text { Menjelaskan pengertian nilai dan } \\
\text { norma sosial }\end{array}$ & C2 & 1 \\
\hline 2. & $\begin{array}{l}\text { Membedakan ciri-ciri nilai dan } \\
\text { norma sosial }\end{array}$ & C2 & $7,25,28,34$ \\
\hline 3. & $\begin{array}{l}\text { Menentukan fungsi dari nilai sosial } \\
\text { dan norma sosial }\end{array}$ & C4 & $2,3,4,5,8,16,17,20,22,26$ \\
\hline 4. & $\begin{array}{l}\text { Mengelompokkan jenis-jenis nilai } \\
\text { dan norma sosial }\end{array}$ & C4 & $\begin{array}{l}6,9,10,11,12,13,14, \\
15,23,24,29,35\end{array}$ \\
\hline 5. & Proses terbentuknya norma sosial & C4 & $18,19,21,27,30,31,32,33$ \\
\hline & Jumlah soal & 35 \\
\hline
\end{tabular}

Jurnal Sikola: Jurnal Kajian Pendidikan dan Pembelajaran Vol. 2, No. 4, Th. 2021 
Selanjutnya hasil skor pretest dan postetst peserta didik terlebih dahulu diuji normalitas dan homogenitasnya. Uji normalitas yang digunakan untuk melihat normal atau tidak normalnya data dan uji homogenitas digunakan untuk melihat varian data.

\section{Uji Normalitas}

Uji normalitas dilakukan untuk menentukan apakah data penelitian terdistribusi normal atau tidak, dilakukan dengan menggunakan Uji Liliefors sehingga diperoleh harga $\mathrm{L}_{0}$ dan $\mathrm{L}_{\text {tabel }}$ pada taraf nyata 0,05 . Uji normalitas dilakukan terhadap data skor posttest dan pretest. Hasil uji normalitas dapat dilihat pada tabel 2.

Tabel 2. Hasil Uji Normalitas Skor Posttest dan Pretest

\begin{tabular}{lcccl}
\multicolumn{1}{c}{ Test } & $\mathbf{N}$ & $\mathbf{L}_{\mathbf{0}}$ & $\mathbf{L}_{\text {tabel }}$ & Distribusi \\
\hline Awal (Pretest) & 34 & 0,141 & 0,151 & Normal \\
\hline Akhir (Posttest) & 34 & 0,084 & 0,151 & Normal \\
\hline
\end{tabular}

\section{Uji Homogenitas}

Uji homogenitas dilakukan untuk menentukan apakah kedua data penelitian memiliki varians yang homogen atau tidak dengan menggunakan uji $\mathrm{F}$ sehingga diperoleh harga $\mathrm{F}_{\text {hitung }}$ dan $F_{\text {tabel }}$ pada taraf nyata 0,05 . Uji $\mathrm{F}$ dapat dilihat pada tabel 3.

Tabel 3. Hasil Uji Homogenitas Skor Posttest dan Pretest

\begin{tabular}{ccccc}
\multicolumn{1}{c}{ Test } & $\mathbf{S}^{\mathbf{2}}$ & $\mathbf{F}_{\mathbf{h}}$ & $\mathbf{F}_{\mathbf{t}}$ & Keterangan \\
\cline { 1 - 2 } Awal (Pretest) & 146,65 & \multirow{2}{*}{1,80} & \multirow{2}{*}{1,82} & Homogen \\
\cline { 1 - 2 } Akhir (Posttest) & 264,71 & & & \\
\hline
\end{tabular}

\section{Uji Hipotesis}

E-modul ini disebut efektif apabila kemampuan penguasaan materi peserta didik meningkat. Hasil dari uji efektifitas ini diperoleh dari nilai pretest-posttest yaitu peserta didik mengerjakan soal objektif sebanyak 35 soal yang sudah dinyatakan layak untuk digunakan pada penelitian pengembangan e-modul sebelumnya. Efektivitas e-modul dapat dilihat dari uji kesamaan rata-rata skor hasil pretest dan posttest, kemudian mengacu pada nilai di atas kriteria ketuntasan minimal (KKM) yang ditetapkan sekolah. Bila terdapat perbedaan dari hasil uji kesamaan rata-rata skor pretest-posttest maka penggunaan e-modul dinilai efektif. Setelah itu skor posttest peserta didik dikatakan tuntas jika skor peserta didik berada di atas KKM. Jika dua hal ini tercapai maka penggunaan e-modul pembelajaran sosiologi berbasis anyflip dapat dikatakan efektif sebagai sumber belajar peserta didik pada pembelajaran sosiologi SMA kelas XI, khususnya materi nilai dan norma sosial pada peserta didik di kelas XI IPS 4 SMAN 3 Payakumbuh.

Uji hipotesis dilakukan untuk memperkuat dugaan dari hipotesis penelitian yang telah dirumuskan. Uji hipotesis dilakukan setelah melakukan uji normalitas dan uji homogenitas terhadap data penelitian yang berasal dari nilai selisih posttest dan pretest. Hasil yang diperoleh adalah data penelitian berasal dari kelas subjek yang terdistribusi normal dan homogen. Oleh sebab itu untuk melakukan uji hipotesis digunakan uji kesamaan dua rata-rata (uji t), yang secara ringkas dapat dilihat pada tabel 4.

Tabel 4. Hasil Uji Homogenitas Skor Posttest dan Pretest

\begin{tabular}{|c|c|c|c|c|c|}
\hline Test & Mean & $\mathbf{S}^{2}$ & $t_{\text {bitut }}$ & $t_{\text {toh }}$ & Keterangan \\
\hline Awal (Pretest) & 72,82 & 141.61 & & 1671 & $\mathrm{Te}$ \\
\hline Akhir (Posttest) & 87,05 & 39,25 & & & Pengaruh \\
\hline
\end{tabular}

Jurnal Sikola: Jurnal Kajian Pendidikan dan Pembelajaran Vol. 2, No. 4, Th. 2021 
Pada tabel di atas diperlihatkan ringkasan hasil statistik deskriptif dari nilai pretest dan posttest. Untuk nilai pretest diperoleh rata-rata hasil belajar atau mean sebesar 72,82 . Sedangkan untuk nilai posttest diperoleh nilai rata-rata hasil belajar sebesar 87,05. Jumlah peserta didik yang digunakan sebagai sampel penelitian berjumlah 34 peserta didik. Untuk nilai standar deviasi pada pretest sebesar 11,90 dan posttest sebesar 6,49. Karena nilai rata-rata hasil belajar pada pretest 72,82 $<$ posttest 87,05 , maka artinya secara deskriptif ada perbedaan rata-rata hasil belajar antara pretest dan posttest. Kemudian analisis dapat dilakukan dengan melakukan perbandingan nilai perhitungan $\mathrm{t}_{\text {hitung }}$ dan $\mathrm{t}_{\text {tabel. }}$. Nilai $\mathrm{t}_{\text {hitung }}$ yang diperoleh adalah 1,80 dan nilai $\mathrm{t}_{\text {tabel }}$ dengan $\mathrm{df} 66$ adalah 1,671, sehingga nilai $t$ hitung $>t_{\text {tabel. }}$. Hasil ini meperlihatkan bahwa terdapat pengaruh penggunaan e-modul berbasis anyflip pada pembelajaran sosiologi SMA kelas X IPS 4 materi nilai dan norma sosial terhadap hasil belajar mereka. Artinya penggunaan e-modul berbasis anyflip pada pembelajaran sosiologi SMA kelas X materi nilai dan norma sosial efektif dan mampu meningkatkan hasil belajar peserta didik di kelas X IPS 4 SMAN 3 Payakumbuh, khususnya materi nilai dan norma sosial. Selanjutnya skor rata-rata yang diperoleh peserta didik saat diberikan soal posttest adalah 87,05 , sehingga dapat dikatakan semua peserta didik tuntas mengikuti pembelajaran sosiologi materi nilai dan norma sosial.

Peserta didik di keals X IPS 4 SMAN 3 Payakumbuh yang belajar melalui e-modul berbasis anyflip dapat terbantu selama proses pembelajaran pada pandemi covid-19, karena modul ini dapat membuat peserta didik belajar secara mandiri. Selain itu pada e-modul ini terdapat langkahlangkah pembelajaran sesuai dengan model pembelajaran yang dirancang oleh guru. Kelebihan yang dimiliki oleh e-modul ini antara lain adalah : peserta didik memiliki pengetahuan awal dari peta konsep dan fenomena yang disajikan pada bagian awal e-modul, sehingga mereka mengenai materi yang akan dipelajari, membangun rasa ingin tahu dan muncul motivasi peserta didik untuk mengetahui lebih jauh mengenai materi ini sehingga peserta didik berusaha membuat koneksi tentang pengetahuan sebelumnya dengan pengetahuan yang akan dipelajari.

Konsep tersebut ditemukan, diperkenalkan dan dibentuk melaluipertanyaan-pertanyaan yang dapat membuat siswa berpikir kritis dan analitis. Peserta didik dapat menemukan konsep dalam kegiatan eksplorasi dan pembentukan konsep karena proses mengamati dan membaca emodul berbasis anyflip, mendengar penjelasan dari guru,menjawab pertanyaan-pertanyaan yang diajukan melakukan kegiatan belajar kelompok (diskusi) dan menyimpulkan hasil diskusi yang diperoleh, sehingga peserta didik menemukan konsepsecara mandiri. Sanjaya (Sanjaya, 2006) berpendapat bahwa belajar bukan hanya sekedar menghafal sejumlah kata atau informasi. Belajar adalah berbuat, memperoleh pengalaman tertentu sesuai dengan tujuan yang diharapkan. Dalam e-modul ini juga terdapat soal latihan agar peserta didik dapat mengukur sendiri penguasaan materinya, pemahaman peserta didik mejadi lebih baik dan dapat melatih kemampuannya untuk memecahkan masalah yang berhubungandengan konsep yang telah diperoleh sebelumnya. Ketika konsep yang diterapkan dalam bentuklatihan soal berhasil, siswa bisa berintegrasi dengan konsep lainnya (Hanson, 2005).

E-modul berbasis anyflip pada materi nilai dan norma sosial dirancang memiliki tampilan dengan warna yang menarik, dilengkapi dengan gambar, tabel, informasi pembelajaran, pertanyaan-pertanyaan dan soal latihan yang memudahkan siswa dalam belajar. E-modul berbasis anyflip ini juga berisi kalimat yang mudah untuk di pahami, dan terdiri dari gambargambar yang menarik yang memudahkan peserta didik untuk memahami materi. Menurut Arsyad (Arsyad, 2013) perancangan pengajaran harus berupaya membuat media berbasis teks (modul) menjadi interaktif. Penyajian informasi harus dalam jumlah selayaknya yang dapat dicerna, diproses dan dikuasai. (Nella \& Sylvia, 2020). Keberhasilan penyajian materi dengan modul sangat ditentukan oleh warna, huruf dan kotak untuk menarik perhatian siswa terutama untuk menetukan informasi yang penting. Akhirnya beberapa kelebihan yang dimiliki oleh emodul berbasis anyflip untuk pembelajaran sosiologi SMA kelas XI khususnya materi nilai dan norma sosial mendukung hasil pengumpulan data yang menyatakan e-modul ini efektif.

Jurnal Sikola: Jurnal Kajian Pendidikan dan Pembelajaran Vol. 2, No. 4, Th. 2021 


\section{Kesimpulan}

Dari hasil penelitian maka dapat disimpulkan bahwa elektronik modul berbasis anyflip adalah e-modul yang digunakan secara online. Uji hipotesis dilakukan dengan menggunakan formula uji $\mathrm{t}$ ( $\mathrm{t}$-test) yang memperlihatkan nilai $\mathrm{t}$ hitung yang diperoleh adalah 1,80 dan nilai $\mathrm{t}$ tabel dengan df 66 adalah 1,671, sehingga nilai $t$ hitung $>t$ tabel. Hasil ini meperlihatkan bahwa terdapat pengaruh penggunaan e-modul berbasis anyflip pada pembelajaran sosiologi SMA kelas X IPS 4 materi nilai dan norma sosial terhadap hasil belajar mereka. Artinya penggunaan e-modul berbasis anyflip pada pembelajaran sosiologi SMA kelas X materi nilai dan norma sosial efektif dan mampu meningkatkan hasil belajar peserta didik di kelas X IPS 4 SMAN 3 Payakumbuh, khususnya materi nilai dan norma sosial. E-modul ini dilengkapi dengan komponen dan tampilan yang menarik sehingga dapat membantu peserta didik menguasai materi dan sesuai dengan karakteristik peserta didik.

\section{Daftar Pustaka}

Arsyad, A. (2013). Media Pembelajaran. Jakarta: Raja Grafindo.

Depdiknas. (2016). Penilaian. Jakarta: Raja Grafindo Persada.

Fajaryati, N., Nurkhamid, N., Pranoto, P. W., Muslikhin, M., \& Dwi W, A. (2016). E-Module Development for the Subject of Measuring Instruments and Measurement in Electronics Engineering Education. Jurnal Pendidikan Teknologi Dan Kejuruan, 23(2), 191. https://doi.org/10.21831/jptk.v23i2.12302

Grasindo, T. (2017). UUD 1945 dan Amandemennya Untuk Pelajar dan Umum. Jakarta: PT. Gramedia Widiasarana Indonesia.

Hanson, D. M. (2005). Designing Process-Oriented-Inquiry Activities. In Faculty Guidedbook: A Comprehensivw Tool For Improving Faculty Performance, ed S. W(Beyerlein and D.K Apple, ed.). Lisle IL: Pacific Crest.

Ibda, F. (2015). Perkembangan Kognitif Teori Jean Piaget. Jurnal Intelektual, 3(1), 27-38.

Kunandar. (2013). Penilaian Autentik (Penilaian Hasil Belajar Peserta Didik Berdasarkan Kurikulum 2013). Suatu Pendekatan Praktis Disertai Dengan Contoh. Jakarta: Rajawali Press.

Majid, A. (2013). Strategi Pembelajaran. Bandung: PT Remaja Rosdakarya.

Nella, S. R., \& Sylvia, I. (2020). Pengembangan Media Komik pada Mata Pelajaran Sosiologi untuk Meningkatkan Pemahaman Siswa. Jurnal Sikola: Jurnal Kajian Pendidikan Dan Pembelajaran, 1(3), 227-237. https://doi.org/10.24036/sikola.v1i3.32

Permana, M. S., \& Johar, J. (1999). Strategi Pembelajaran. Jakarta: Direktorat Jendral Pendidikan Tinggi.

Purwanto, R., \& Lasmono, L. (2007). Pengembangan Modul. Jakarta: Pusat Teknologi Informasi dan Komunikasi Pendidikan (PUSTEKOM).

Sanjaya, W. (2006). Strategi Pembelajaran Berorientasu Standar Proses Pendidikan. Jakarta: Kencana.

Sudjana, N. (2010). Proses dan Hasil Belajar. Jakarta: Bumi Aksara.

Syahrial, Asrial, Kurniawan, D. A., \& Piyana, S. O. (2019). E-Modul Etnokontruktivisme: Implementasi Pada Kelas V Sekolah Dasar Ditinjau Dari Persepsi, Minat Dan Motivasi. JTP - Jurnal Teknologi Pendidikan, 21(2), 165-177. https://doi.org/10.21009/jtp.v21i2. 11030

Wahidmurni, W., Mustikawan, A., \& Ridho, A. (2010). Evaluasi Pembelajaran: Kompetensi dan Praktik. Yogyakarta: Nuha Letera. 